\title{
Radio Frequency Identification and Image-Based Facial Identification as an Employee Attendance System
}

\author{
Raden Andy Kurniawan ${ }^{1}$, Umar Zaky ${ }^{2}$ \\ ${ }^{1}$ Program Studi Informatika,Fakultas Teknologi Informasi dan Elektro, Universitas Teknologi Yogykarta \\ ${ }^{2}$ Program Studi Sistem Informasi,Fakultas Teknologi Informasi dan Elektro, Universitas Teknologi Yogykarta \\ E-mail : andykurniawan009@gmail.com ${ }^{1}$, umar.zaky@ staff.uty.ac.id $^{2}$
}

\begin{abstract}
The current development of microcontroller technology can be used to build a presence system for employees. The employee attendance system uses radio frequency identification and facial identification which is designed and built to make it easier to do attendance data recording, so that the data obtained can be precise and accurate. Data collection techniques, namely by interview and observation. The application development process uses the PHP and Python programming languages with Visual Studio Code software applications, Arduino Uno, MySQL software as a database server, and XAMPP as a support. The input used in this system is the employee's personal data and the results of employee face data retrieval which are stored in the .jpg format. The faces taken were taken from 4 people where each face was taken 20 face samples. The results are in the form of web and applications that will provide solutions to existing problems. The conclusion of this application makes it easy to do the recording and attendance, and minimize the fraud committed by employees. Retrieval of face data was taken as much as 20 data with the highest level of accuracy was $87 \%$ when the presence test was carried out.
\end{abstract}

Keywords: presence, radio frequency identification, face identification

\section{INTRODUCTION}

\subsection{Background}

Fingerprint presence system often cause problems when used. Problems that arise from the presence of fingerprints are due to the many fingerprints that are stuck, wet due to sweat from someone's fingers, and also sometimes fingers that have problems such as peeling, getting inked so that it interferes with the identification process. This fingerprint recognition method is one of biometrics.

There are several biometric method that can be applied to the presene system, that is facial presence, iris presence, palm presence, and fingerprint presence. By looking at the problems that have occurred before with the presence system using fingerprints, the authors want to develop a presence system that uses facial biometrics as its object, there are many methods that can be used to process images such as the Histogram of Oriented Gradients (HOG), Haar Wavelet, PCA-SIFT, Shape Contexts and others. The author chose to use the method Histogram of Oriented Gradients (HOS) because it greatly outperformed Haar Wavelet, PCA-SHIFT, Shape Contexts and provided perfect separation results based on previous research conducted by Dalal and Triggs.

\subsection{Problem Formulation}

Research Radio Frequency Identification and Image-Based Face Identification as an System Employee Presence includes various matters, as follows:

a. The system cannot manage payroll yet.

b. The system cannot detect faces if most of the faces are covered by other objects.

c. The system uses the method Histogram of Oriented Gradients (HOG).

d. Attendance is done at the beginning and end of working hours.

e. This system is designed for the Morobongo village office, Temanggung.

\section{THEORITICAL FRAMEWORK}

\subsection{System}

According to ${ }^{[10]}$ Mustakini et al., (2016) The system is a set of interrelated or integrated elements that are intended to achieve a unit consisting of two or more components or subsystems that interact to achieve a goal. 


\subsection{Radio Frequency Identification (RFID)}

According to ${ }^{[2]}$ Asfi and Sari (2010) Radio frequency identification is a technology to identify a person or object using radio frequency transmissions, particularly $125 \mathrm{kHz}, 13.65 \mathrm{MHz}$ or $800-900 \mathrm{MHz}$. RFID uses radio wave communication to uniquely identify an object or person. There are several definitions, namely:

a. RFID (Radio Frequency Identification) is an identification method using a means called an RFID label or transponder (tag) to store and retrieve data remotely.

b. A label or transponder (tag) is an object that can be attached or inserted into a product, animal or even human for identification using radio waves. The RFID label consists of a cilicon microchip and antenna.

\subsection{Artificial Intelegence (AI)}

According to ${ }^{[12]}$ Artificial intelligence (AI) is a study of how to make computers do things at this time can be done better by humans.

To carry out artificial intelligence applications, there are 2 main parts that are needed, namely:

a. Knowledge Base contains facts, theories, ideas and relationships with one another.

b. Inference Engine namely the ability to draw conclusions based on experience.

\subsection{Face Recognition}

According to ${ }^{[8]}$ face recognition is the process of recognizing faces in which the brain and mind try to interpret, understand, and interpret the faces in front of them, especially human faces. Basically, a facial recognition system must be able to distinguish faces from a background image.

\subsection{Histogram}

According to ${ }^{[3]}$ histogram is form of bar chart that is able to display the distribution of spatially disordered image calculations in an area and the relative invariant of some object transformations in the image.

\subsubsection{Definition of the Histogram of Oriented}

\section{Gradients}

According ${ }^{[3]}$ descriptor of the Histogram of Oriented Gradients (HOG) is that the appearance of objects and local shapes in an image can be described by the distribution of the intensity or direction of the gradient epi. The application of descriptor this can be achieved by dividing the image into small connected areas, called cells, and for each cell a histogram is compiled with the gradient direction or edge orientation for each pixel in the cell. The combined histograms then state the descriptor. Meanwhile, the gradient on each pixel is obtained by applying filters $\left[\begin{array}{lll}-1 & 0 & 1\end{array}\right]$ and [-1 $\left[\begin{array}{ll}-1 & 1\end{array}\right] \mathrm{T}$ [2].

\section{a. Detector Window}

Detector Window is a $64 \times 64$ window that is used for this detection window consisting of $4 \times 4$ pixels in each cell

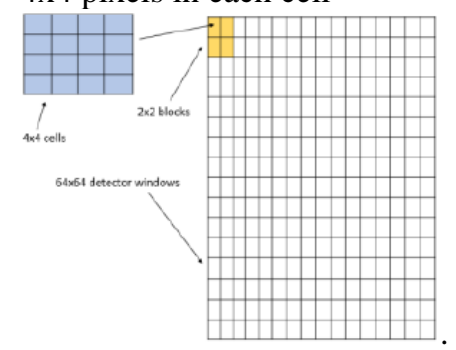

Figure 2. 1 Detector Window

\section{b. Convert Image or Color Normalization}

Image true color is representation of the color image which has three main components namely RGB. Each component in the image true color has 256 possible values. Image greyscale has 28 (256) possible pixel values. The values start at zero for black and 255 for white. Conversion of image true color to greyscale changes the pixel value which originally had 3 values, namely RGB to 1 value, namely gray. The following equation is used to get the gray value:

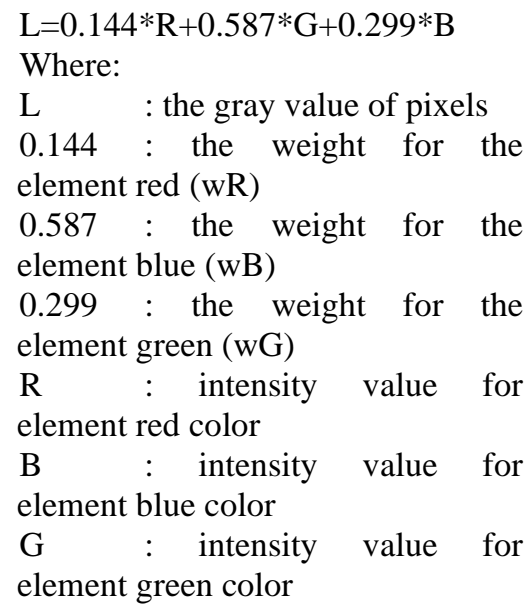

\section{c. Gradient Compute}

After the image conversion process, which is changing the image to form greyscale, the 
next step is to calculate the gradient value for each pixel in the image.

\section{d. Spatial Orientation Binning}

To make a histogram, a gradient value is needed and this value is obtained from the value of each pixel in the image. The image will then be divided into cells of the specified size. So, each cell in the image will be made a histogram to find out the value in each cell because each cell has a different value. In making the histogram, a bin is needed to determine the gradient value.

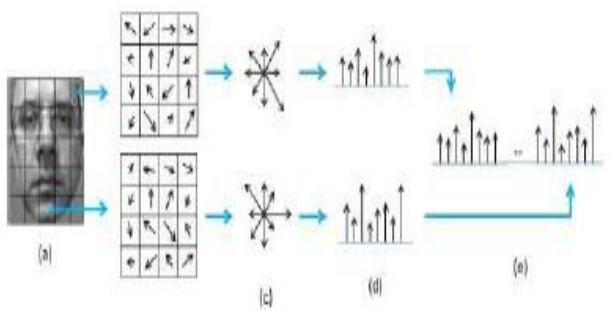

Figure 2. 2 Spatial Orientation Binning

\section{e. Normalization Block}

Because the values gradient have different values, it is necessary cells to group largeror what is called a block. The blocks usually overlap because each cell.

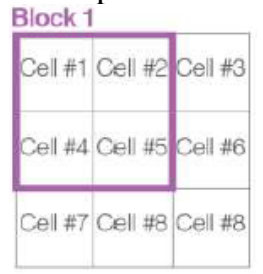

Figure 2. 3 Normalisasi Block

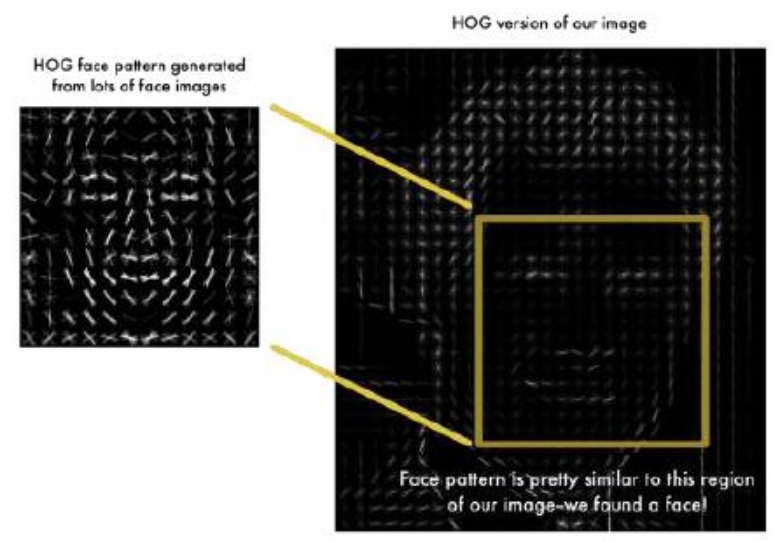

Figure 2. 4 Getting Descriptor HOG

\subsection{Website}

According to ${ }^{[5]}$ website is an online presentation medium for a company or individual. The website can also be used as a medium for delivering information online, such as detik.com, okezone.com, vivanews.com and others.

\subsection{Database}

According to ${ }^{[14]}$ database is a collection of data that are interrelated. Data are facts about objects, people, and others. Data is represented by values (numbers, strings, or symbols).

\section{RESULTS AND DISCUSSION}

\subsection{System Analysis}

This system analysis aims to determine the flow of the system that is already running because the system being built later must be able to translate the real conditions of the actual test implementation, so that the system built can function properly.

\subsubsection{The Running System}

The system currently running still uses books to recapitulate attendance where employees sign the entry and return columns. So that it can allow fraud in making attendance, and data errors can occur in the employee attendance recapitulation.

\subsubsection{Analysis of The Proposed System}

The system proposed by the researcher is RFID and image-based face identification as an employee attendance system. So that with this system, it is expected that the agency can recapitulate the presence of employee more accurately.

\section{a. Functional Analysis}

Functional requirements are the requirements that users need when using the system. The following are functional requirements, including:

1. Input employee data.

2. Input job data.

3. Employee attendance time setting.

4. Employee attendance data information.

\section{b. Non Functional Analysis.}

Non-Functional Requirements are needs that do not have a direct relationship to the system being created.

1. Software requirements

The software or software needed in making this system are : 

a. Windows $7 / 8 / 10$
b. XAMPP
c. Visual Code
d. MySQL

\section{Hardware requirements}

The hardware or hardware required in making this system are:
a. Katru RFID / Tag RFID
b. RFID MRC522
c. NodeMCU 8266
d. LCD I2C

\subsection{Perancangan Sistem}

Design is a stage that aims to design or design a structured system where in system design there are steps operationalin data processing and processes to support the system being created. System design aims to meet the needs of system users and provide a clear picture and complete design. The following is the flowchart of the system design shown in Figure 4.1.

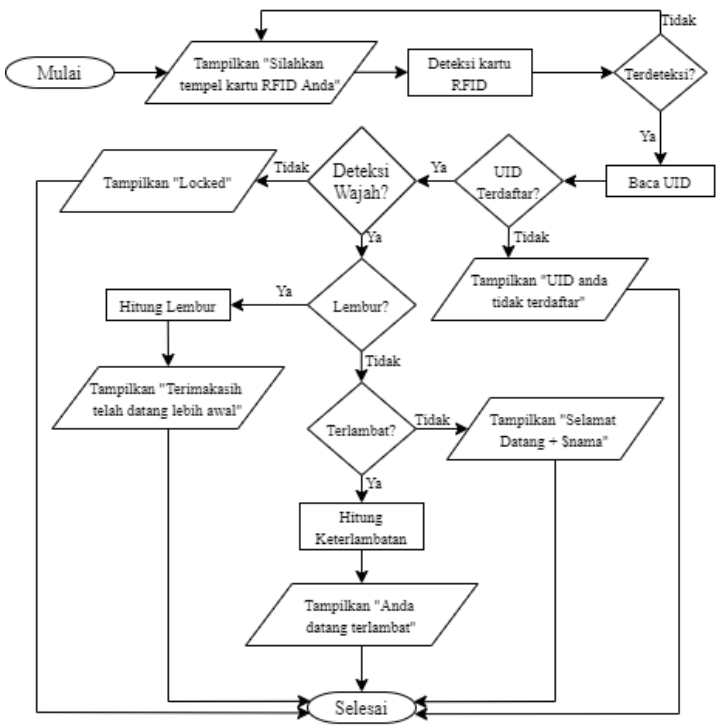

Figure 3. 1 Flowchart System

The system flowchart describes how the system runs, starting from the system that displays the message "Please paste your RFID card", then if a card is detected by the system, the system will read the UID on the card. If the UID is not registered then the system will display the message "your UID is not registered". If the UID is registered by the system then proceed to the face scan process, if the face is not detected, the program will display a "Locked" warning. When a registered face is detected, the system will stop recording the face, and continue to check the working hours, if overtime the system will display the message "Thank you for coming early", if it is too late the system will display the message "You are late". And if it arrives on time, the system will display the message "Welcome+\$name". Process complete.

\subsection{Process Modeling}

The process modeling of the proposed system uses the Unified Modeling Language (UML) as follows:

\subsubsection{Usecase Diagram}

The diagram presents the interaction between usecase and actors. Where it can be people, equipment or other systems that are being built. Usecase describes the system functionality or requirements the system must meet from the user's perspective.

Usecase represents the operations performed by the actor. In the proposed system, there are 3 actors who can interact with the system, namely admin, HRD, and employees. The following is the usecase design in this study:

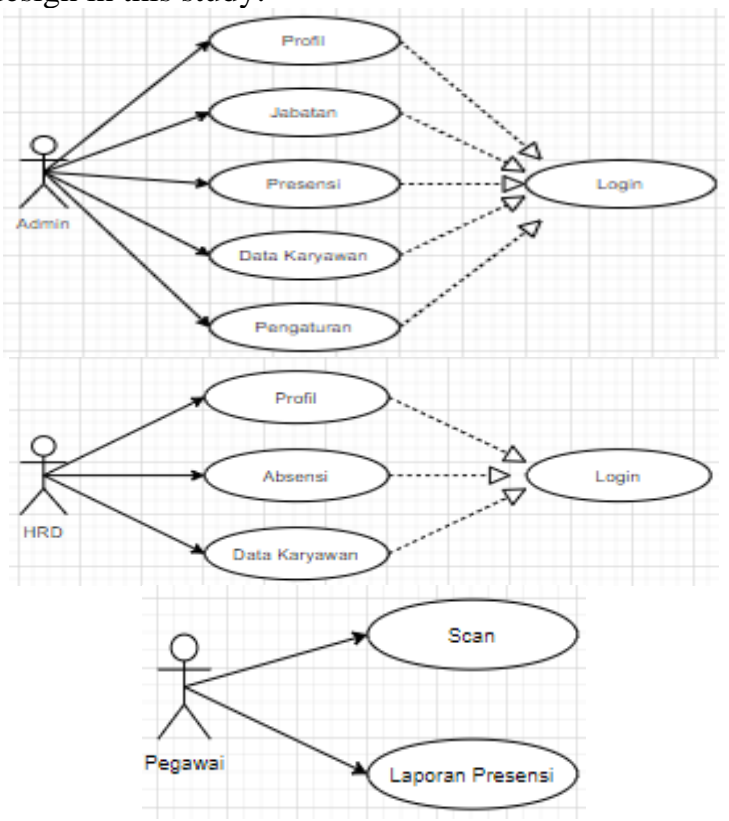

Figure 3. 2 Usecase Diagram

Tabel 3. 1 Description of Actor

\begin{tabular}{|l|l|l|}
\hline No & Actor & Description \\
\hline 1 & Admin & $\begin{array}{l}\text { Actors who manage HRD and } \\
\text { employee data, and manage } \\
\text { morning and evening shifts. }\end{array}$ \\
\hline 2 & HRD & $\begin{array}{l}\text { Actors who have access rights to do } \\
\text { attendance see attendance } \\
\text { reports. }\end{array}$ \\
\hline 3 & Employees & $\begin{array}{l}\text { Actors who can only do attendance, } \\
\text { see attendance reports. }\end{array}$ \\
\hline
\end{tabular}


Tabel 3. 2 Usecase Deskripsi

\begin{tabular}{|c|c|c|c|}
\hline No & $\begin{array}{l}\text { Usecase } \\
\text { Name }\end{array}$ & Description & Actor \\
\hline 1 & Login & $\begin{array}{l}\text { Use Case describes } \\
\text { the activity of } \\
\text { entering a } \\
\text { username and } \\
\text { password to access } \\
\text { the system }\end{array}$ & $\begin{array}{l}\text { Admin dan } \\
\text { HRD }\end{array}$ \\
\hline 2 & Position & $\begin{array}{l}\text { Use Case describes } \\
\text { the activities of } \\
\text { managing positions } \\
\text { such as deleting } \\
\text { positions, adding } \\
\text { positions, editing } \\
\text { positions }\end{array}$ & Admin \\
\hline 3 & Profiles & $\begin{array}{l}\text { Use Case describes } \\
\text { the activities of } \\
\text { managing data, } \\
\text { editing profiles }\end{array}$ & $\begin{array}{l}\text { Admin and } \\
\text { HRD }\end{array}$ \\
\hline 4 & $\begin{array}{l}\text { Employee } \\
\text { Data }\end{array}$ & $\begin{array}{l}\text { Use Case describes } \\
\text { the activities of } \\
\text { managing employee } \\
\text { data, adding, editing } \\
\text { schedules, deleting } \\
\text { employee schedules }\end{array}$ & Admin \\
\hline 5 & Attendance & $\begin{array}{l}\text { Use Case describes } \\
\text { the activity of } \\
\text { viewing and printing } \\
\text { presence data that } \\
\text { has been verified on } \\
\text { the system }\end{array}$ & $\begin{array}{l}\text { Admin and } \\
\text { HRD }\end{array}$ \\
\hline 6 & Scan & $\begin{array}{l}\text { Use Case describes } \\
\text { attendance } \\
\text { activities }\end{array}$ & $\begin{array}{l}\text { Admin, } \\
\text { HRD and } \\
\text { Employee }\end{array}$ \\
\hline 7 & $\begin{array}{l}\text { Attendance } \\
\text { report }\end{array}$ & $\begin{array}{l}\text { Use Case describes } \\
\text { the activity of } \\
\text { seeing the presence } \\
\text { data that has been } \\
\text { verified on the } \\
\text { system }\end{array}$ & $\begin{array}{l}\text { Admin, } \\
\text { HRD and } \\
\text { Employee }\end{array}$ \\
\hline
\end{tabular}

\subsubsection{Activity Diagram}

Activity Diagram is a menu in the software. What needs to be shown here is that the activity diagram depicts system activity, not what the actors running the application do, so activities that the system can perform.

\subsubsection{Class Diagram}

Class diagram illustrates the structure of the system in terms of defining the classes that will be made to build the system. Class diagrams are made so that program makers or programmers make classes according to the design in the class diagram so that design documentation and software can be synchronized.

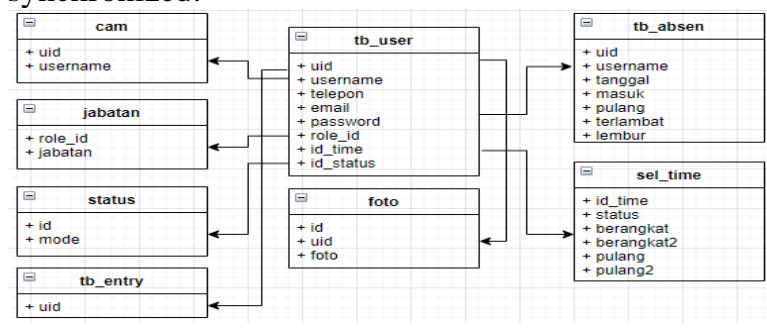

Figure 3. 3 Class Diagram of Attendance System

\subsubsection{Sequence Diagram}

Describes the interaction between several objects for a certain time period and also emphasizes the interaction of a set of objects at a time or on their relationship. Sequence Diagrams can explain the flow of messages between objects when running a Use Case. The following is a Sequence Diagram that explains the flow of messages between objects in the Use Case activity of the proposed system application design.

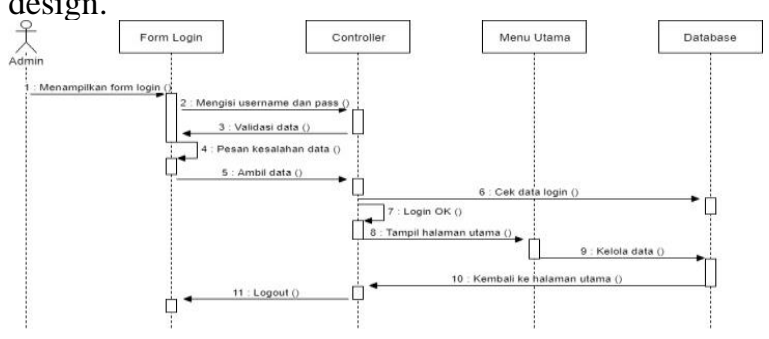

Figure 3. 4 Login Sequence Diagram

Description: The above activity describes the flow of the login process into the system by entering the login page, then filling in the username and password, the system will validate, if the username and password are entered incorrectly, the system will send a data error message, if entered correctly, the system will enter into the main page, here the admin can manage data. When finished managing data, return to the main page and log out.

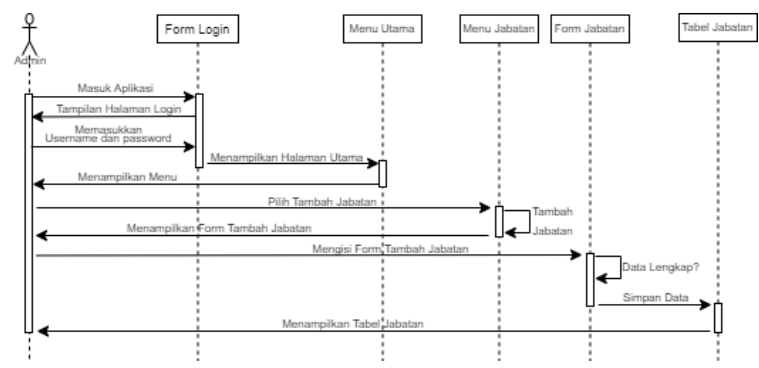

Figure 3. 5 Sequence Diagram Add Position

Description: The above activity describes the process flow for adding a position which is managed by the admin, if the admin wants to add a new position, the 
admin can choose to add a position. After that the system will display a form that must be filled in, if the data entered is incomplete, the system will provide a notification which must be completed later. Then when it's finished, the menu will be saved into the database which will later be displayed to the admin.

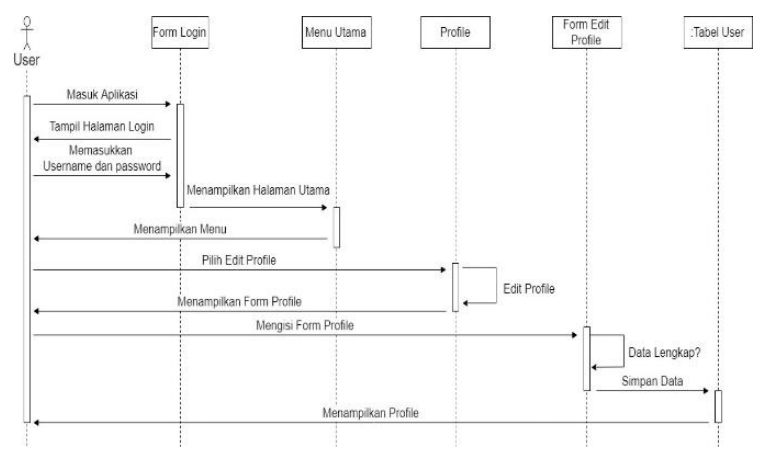

Figure 3. 6 Sequence Diagram Edit Profile

Description: The above activity describes the flow for editing admin and HR profiles. If the user wants to change or update the profile, then the user can select the profile menu. After that the system will display a form which must be filled in completely, if the data entered is not complete, the system will give a warning so that the data is filled in completely. After the data is complete, the data will be saved into the database and the edited profile will be displayed to the user.

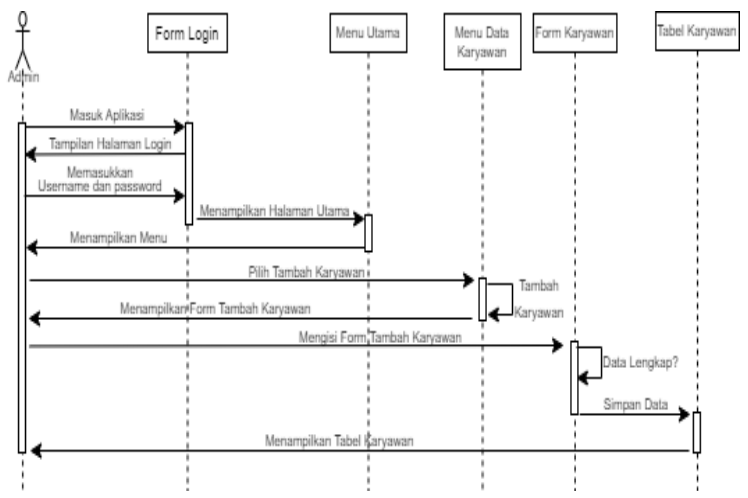

Figure 3. 7 Sequence Diagram of Add Employees

Description: The above activity describes the process flow of managing employee data which can only be managed by the admin. If the admin wants to add, change or delete existing employee data, the admin can select employee data from the menu provided. The system will display what employee data forms if the admin wants to add or change employee data. If the data entered is incomplete, the system will notify you to complete the unfilled data. Then when it's finished, the system will save the data into the database which will later be displayed to the admin.

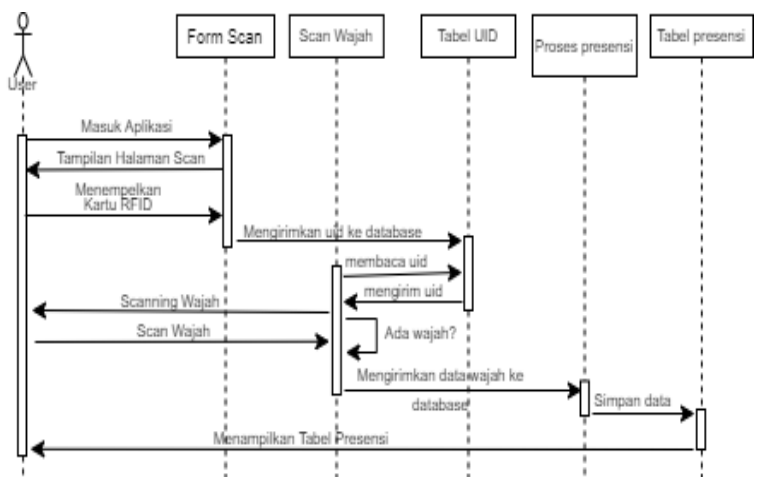

Figure 3. 8 Sequence Diagram of Attendance

Description: The activity above describes the attendance process flow that can be carried out by all employees (admin, HRD, and employees). Employees enter the scan page, to take attendance, the employee must attach the RFID card to the equipment provided. Then the system will validate the suitability of the incoming data, if the UID data matches, the system will ask for a face scan. Then the system will validate the incoming face data with the face data in the database. If the results of the face data are valid with those in the database, then the employee data and attendance information will appear if the face data is valid in the attendance form, which indicates that the employee has taken attendance to enter or leave. Then the data is saved to the database.

\subsection{Implementation}

Application implementation is an explanation of the features contained in applications that have been built.

\subsubsection{Scan Page Display}

The Scan page is the main page of the Employee Attendance System Website using RFID for the Morobongo Village Office, Temanggung Regency. This page functions as a reading area for the RFID card that is tapped into the RFID Reader which is connected to the system via the same network. The Scan Page Display is as follows: 


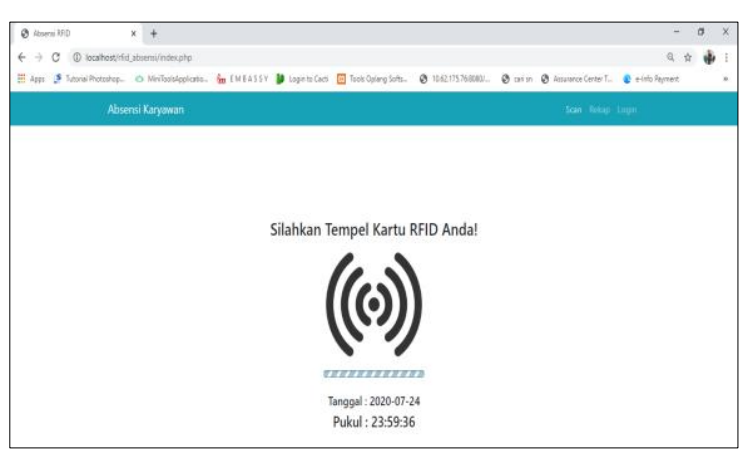

Figure 3. 9 Scan Display

\subsubsection{Login Page Display}

Login page is a page where admin and HRD enter their email and password to go to their respective dashboard. As for employees, access will be denied, so they cannot go to the HRD or admin dashboard. The Login Page Display is as follows:

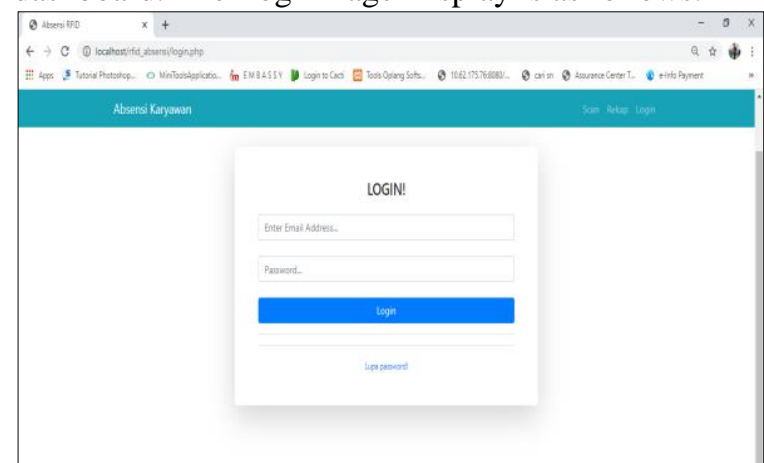

Figure 310 Login Display

\subsubsection{Dashboard Page}

The admin dashboard is the initial display of the website when the admin has successfully logged in. The Admin Dashboard displays as follows:

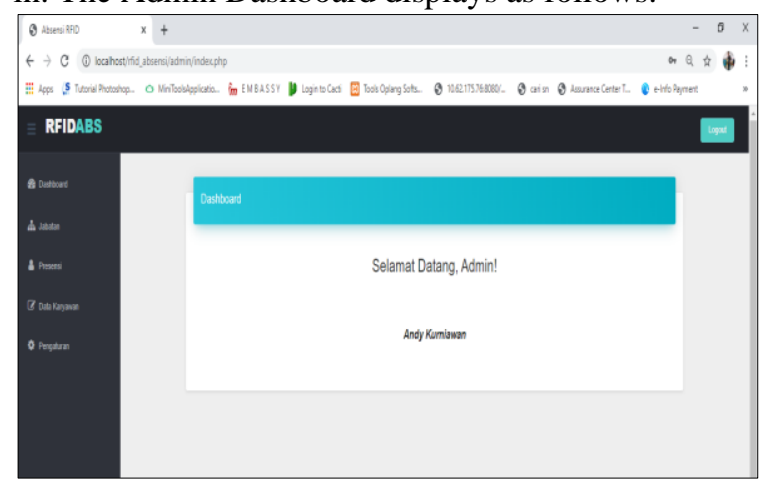

Figure 3. 11 Dashboard Display

\subsubsection{Position Page}

Position page is a form that displays the entire list of positions that have been entered by the admin. The Position Page Views are as follows:

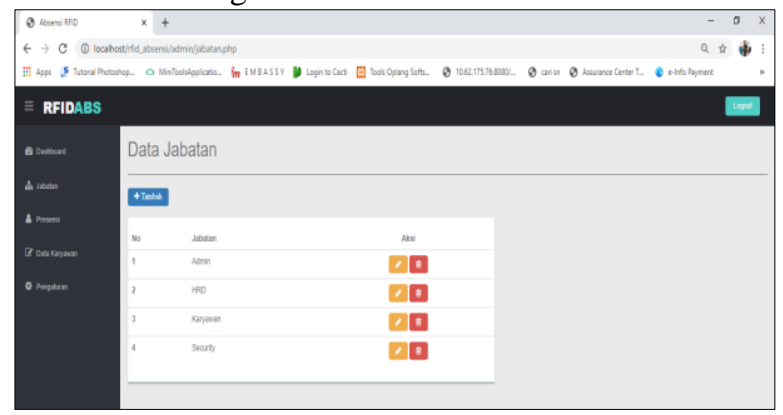

Figure 3. 12 Position Display

\subsubsection{Attendance Page Display}

Attendance page helps admin in recapitulating employee attendance, where admin can print all employee attendance data that has been successfully stored. The Presence Page Views are as follows:

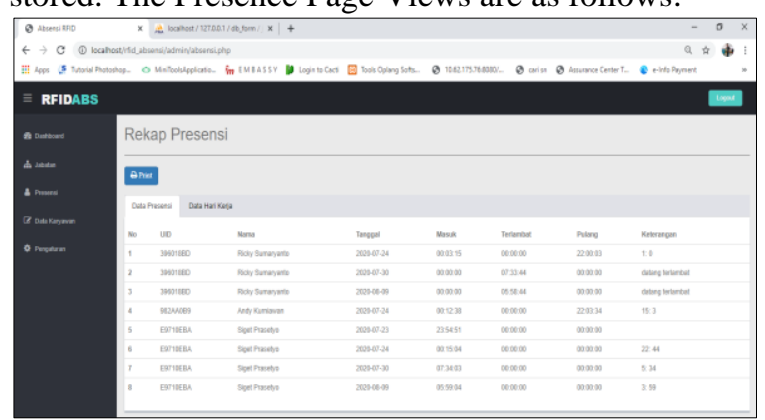

Figure 3.13 Attendance Display

\subsubsection{Employee Data Page Display}

The Employee Data page is a form that displays the entire job list. In this form the admin can add, change or delete employee data. The Employee Data Page Views are as follows:

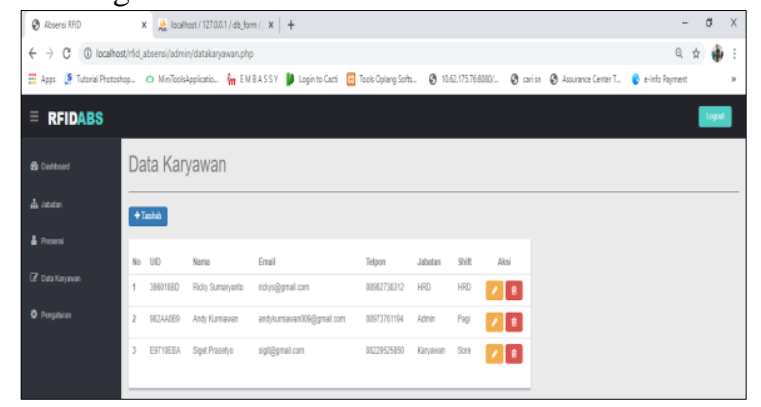

Figure 3. 14 Display Employee Data 


\subsubsection{RFID Card Registration Page}

The RFID Card Register page helps admins add employee data to the system. The RFID Card Register Page Display is as follows:

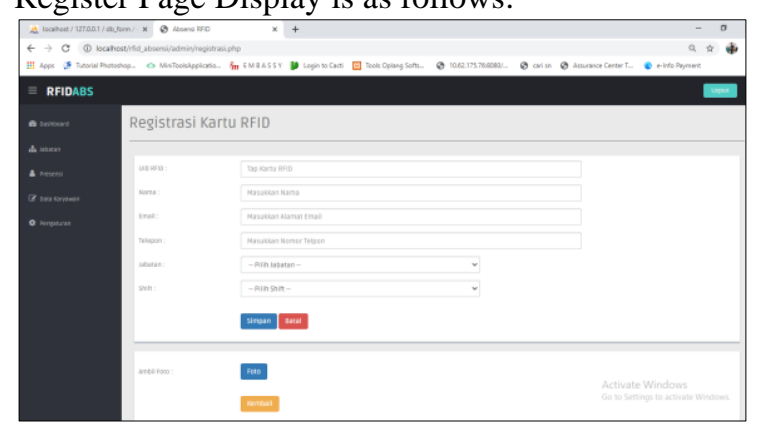

Figure 3. 15 Display of RFID Card Register

\subsubsection{Settings page}

Settings page helps admin in setting employee attendance time according to the shift selected in the system. The Presence Time Setting Page Display is as follows:

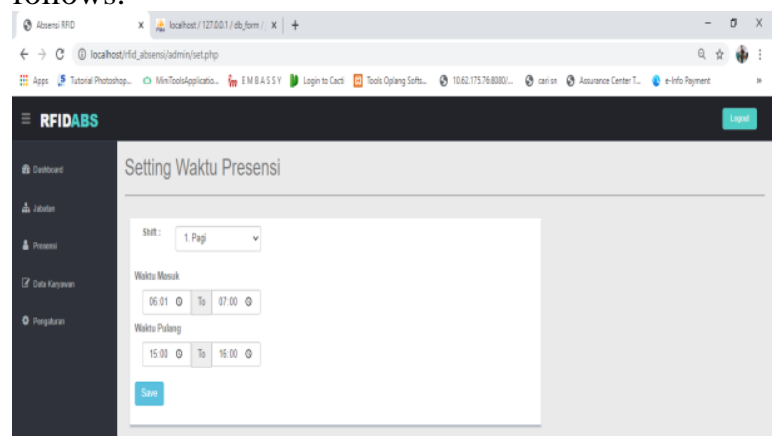

Figure 3.16 Display Settings

\subsubsection{Result}

1. Testing with email is not filled, and other data is filled in as shown below.

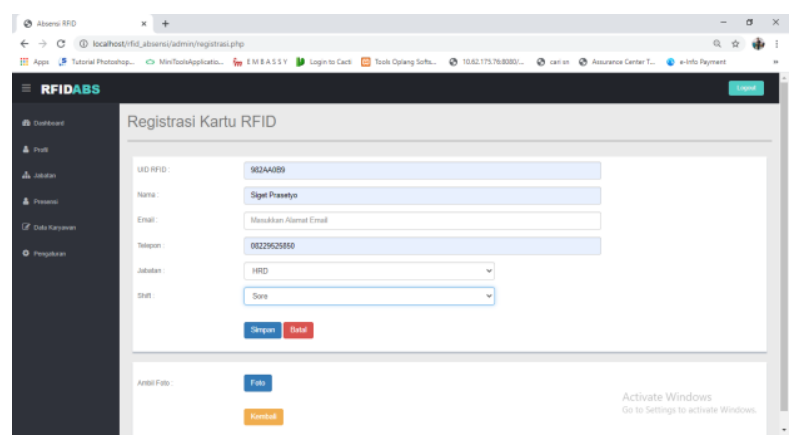

Figure 3. 17 Blank Email Testing
2. The test results are blank email, then a warning will appear as shown below

Warning! Email tidak boleh kosong!

Figure 3.18 Blank Email Test Results

3. Testing by entering data using the UID or email that has been registered in the employee data

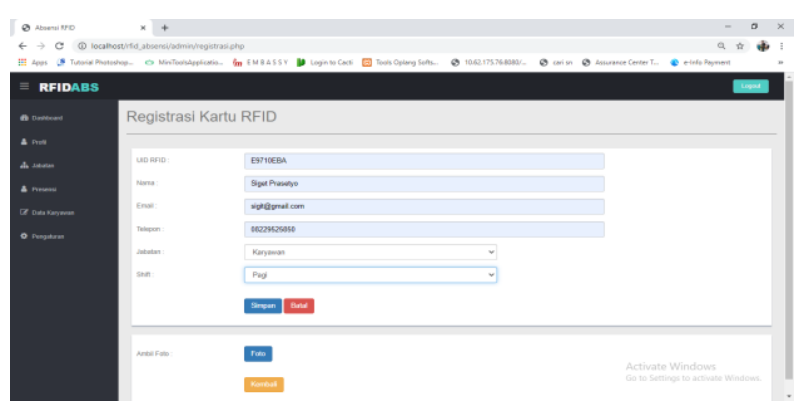

Figure 3.19 Testing the Registration Form

4. The test results on the registration form when entering data using the UID or email that has been registered in the employee data, a warning will appear "Warning! Username already registered "as shown below.

\section{Warning! Username sudah terdaftar}

Figure 3. 20 Registration Form Test Results

\section{CLOSING}

\subsection{Conclusion}

From the results of the research and discussion that has been carried out, the following conclusions can be drawn:

a. The proposed system is able to recognize employee faces, this is evidenced in the test data testing process, faces that are recognized at the time of presence can produce data accuracy of $87 \%$ correctly.

b. Retrieval of face data was taken as much as 20 data with the highest level of accuracy was $87 \%$ when the presence test was carried out. 


\subsection{Suggestion}

The presence system uses radio frequency identification and the image-based face identification that has been made still has a low level of accuracy. This system can be developed using an algorithm that can increase greater accuracy and use training data to capture photos of faces from the right, left, and front. This system can also add camera features to make it better when taking facial photos.

\section{REFERENCES}

[1]Aminah, S.O. (2015), Sistem Informasi Kepegawaian (Studi Kasus: PT Makmur Sexali), Skripsi, S.Pd., Pendidikan T. Informatika Universitas Kepingin Negeri, .

[2]Asfi dan Sari (2010), Sistem Penunjang Keputusan Seleksi Mahasiswa Berprestasi Menggunakan Metode AHP, Skripsi, S.Kom., Universitas Teknologi Yogyakarta.

[3]Dalal, N., and Triggs, B. (2005), Histograms of Oriented Gradients for human detection in IEEE Computer Society Conference on Computer Vision and Pattern Recognition, (CVPR 2005), San Diego. CA. N.

[4]Hermawan, A.M. (2015), Perancangan Sistem Basis
Data, Jakarta: Elex media Komputindo.

[5]Kadir, A. (2013), Pengantar Teknologi Informasi, Yogyakarta: ANDI Publisher.

[6]Cristianini, N., Taylor, J.S. (2000), An Introduction to Support Vector Machine and Other Kernel-Based Learning Methods, Cambridge Press University.

[7]Maulana (2012), Penilaian Kinerja Karyawan Di Ifun Jaya Textile Dengan Metode Fuzzy Simple Additive Weighted, Tugas Akhir, S.Kom., STMIK AMIKOM Yogykarta.

[8]Mustakini, J.H. (2006), Analisis Dan Desain Sistem Informasi: Pendekatan Terstruktur Teori Dan Praktek Aplikasi Bisnis, Yogyakarta: ANDI Publisher.

[9]Mustakini, J.H. (2016), Analisa Dan Perancangan Sistem Modern, Yogyakarta: ANDI Publisher.

[10]Mustakini, J.H. dan Kusumo, M.J. (2016), Analisis Dan Perancangan Sistem Modern, Yogyakarta: ANDI Publisher.

[11]Oetomo, B.S.D. (2003), Sistem Basis Data: Analisis Dan Pemodelan Data, Yogyakarta: Graha Ilmu.

[12]Prahasta, E. (2002), Konsep-Konsep Dasar Sistem Informasi Geografis, Bandung: Informatika.

[13]Sampurna, J. dan Malik, A. (2014), Sistem Pendukung Keputusan, Jakarta: Elex media Komputindo.

[14]Sutarman (2012), Pengantar Teknologi Informasi, Jakarta: Bumi Aksara. 